\title{
Gasotransmitter Regulation of Phosphatase Activity in Live Cells Studied by Three-Channel Imaging Correlation
}

Pan Ou, Ruilong Zhang, Zhengjie Liu, Xiaohe Tian, Guangmei Han, Bianhua Liu, Zhang-J un Hu and Zhongping Zhang

The self-archived postprint version of this journal article is available at Linköping University Institutional Repository (DiVA):

http:// urn.kb.se/ resolve?urn=urn:nbn:se:liu:diva-154661

N.B.: When citing this work, cite the original publication.

Ou, P., Zhang, R., Liu, Z., Tian, X., Han, G., Liu, B., Hu, Z., Zhang, Z., (2019), Gasotransmitter Regulation of Phosphatase Activity in Live Cells Studied by Three-Channel Imaging Correlation, Angewandte Chemie International Edition, 58(8), 2261-2265.

https:// doi.org/ 10.1002/ anie.201811391

Original publication available at:

https:// doi.org/ 10.1002/ anie.201811391

Copyright: Wiley (12 months)

http:// eu.wiley.com/WileyCDA/ 


\title{
Gasotransmitter Regulation of Phosphatase Activity in Live Cells Studied by Three-Channel Imaging Correlation
}

\author{
Pan Ou, Ruilong Zhang, * Zhengjie Liu, Xiaohe Tian, Guangmei Han, Bianhua Liu, \\ Zhangjun $\mathrm{Hu}$, and Zhongping Zhang*
}

\begin{abstract}
Enzyme activity in live cells is dynamically regulated by small molecular transmitters for main-taining normal physiological functions. A few probes have been devised to measure intracellular enzyme activities by fluorescent imaging, but the study of the regulation of enzyme activity via gasotransmitters in situ remains a long-standing challenge. Herein, we report a three-channel imaging correla-tion by a single dual-reactive fluorescent probe to measure the dependence of phosphatase activity on the $\mathrm{H}_{2} \mathrm{~S}$ level in cells. The two sites of the probe reactive to $\mathrm{H}_{2} \mathrm{~S}$ and phosphatase individually produce blue and green fluorescent responses, respectively, and resonance energy transfer can be triggered by their coexistence. Fluorescent analysis based on the threechannel imaging correlation shows that cells have an ideal level of $\mathrm{H}_{2} \mathrm{~S}$ to promote phosphatase activity up to its maximum. Significantly, a slight deviation from this $\mathrm{H}_{2} \mathrm{~S}$ level leads to a sharp decrease of phosphatase activity. The discovery further strengthens our understanding of the importance of $\mathrm{H}_{2} \mathrm{~S}$ in cellular signaling and in various human diseases.
\end{abstract}

$\boldsymbol{E}_{\text {nzymes are the most critical life substances that catalyse }}$ almost all biological reactions such as protein synthesis, energy production and exploitation, and gene expression in cells. ${ }^{[1,2]}$ Thus, the level and activity of enzymes significantly affect the physiological functions of live organisms, and are highly related to various human diseases. ${ }^{[2]}$ While working only at suitable temperatures and $\mathrm{pH}$ environments, many enzymes are temporally activated or inhibited when they are needed in live organisms. ${ }^{[3]}$ In molecular biology it is well known that enzyme activity is intrinsically controlled through one or more pathways of signaling transduction, mainly including the regulation of small molecules and the post-

[*] P. Ou, R. Zhang, Z. Liu, X. Tian, Prof. Z. Zhang

School of Chemistry and Chemical Engineering

and Institute of Physical Science and Information Technology

Anhui University

Hefei, Anhui 230601 (China)

E-mail: zrl@ahu.edu.cn zpzhang@iim.ac.cn

G. Han, B. Liu, Prof. Z. Zhang

Institute of Intelligent Machines, Chinese Academy of Sciences Hefei, Anhui 230031 (China)

Z. $\mathrm{Hu}$

Department of Physics, Chemistry and Biology Linköping University, Linköping 58183 (Sweden)

(2) Supporting information and the ORCID identification number(s) for D the author(s) of this article can be found under: https://doi.org/10.1002/anie.201811391. modification of enzymes themselves. ${ }^{[2]}$ The two pathways determining the activity of an enzyme commonly coexist in live cells. Unlike the study of enzyme activity in vitro, multiple correlations seriously increase difficulties in understanding the regulatory and catalytic mechanisms of enzymes.

Among a myriad of enzymes, phosphatase is an important member of the hydrolase family that dephosphorylate proteins or other enzymes and modulate their biological functions. The activity of phosphatase itself is controlled by other upstream signaling molecules such as reactive oxygen species (ROS) and gasotransmitters. ${ }^{[3]}$ Of these signaling molecules, hydrogen sulfide $\left(\mathrm{H}_{2} \mathrm{~S}\right)$ as a crucial regulator has been studied extensively to clarify its actions on how it affects phosphatase activity, such as its reaction with cysteine (Cys) residue, its coordination with metal ions, and the elimination of ROS. ${ }^{[4]}$ Meanwhile, phosphatase activity is also indirectly modulated by $\mathrm{H}_{2} \mathrm{~S}$ through the reaction with phosphatase upstream biomolecules. ${ }^{[5]}$ Recently, phosphatase activity and the $\mathrm{H}_{2} \mathrm{~S}$ level in live cells have individually been studied by numerous scientists. Due to their high sensitivity and selectivity, fluorescent probes provide a feasible approach for measuring phosphatase activity; a phosphate-conjugated fluorophore serves as a substrate, and cleavage of phosphate by phosphatase leads to a fluorescent "turn on". [6,7] Meanwhile, fluorescent probes for $\mathrm{H}_{2} \mathrm{~S}$ imaging have also been designed by a serial of strategies such as quenching-ion removal, ${ }^{[8]}$ substitution/addition reactions, ${ }^{[9]}$ and azido $\left(-\mathrm{N}_{3}\right)$ group reduction. ${ }^{\left[{ }^{a}, 10,11\right]}$ Although numerous individual phosphatase and $\mathrm{H}_{2} \mathrm{~S}$ probes are available, evaluating the correlation of phosphatase activity to the $\mathrm{H}_{2} \mathrm{~S}$ level has been limited because the synchronous use of two fluorescent probes inevitably leads to large invasive effects, different cellular uptake, and spectral interruption. ${ }^{[12,13]}$

To bypass these barriers, an ideal strategy is to develop a single fluorescent probe with two different reactive sites that can respond to both phosphatase and $\mathrm{H}_{2} \mathrm{~S}$ simultaneously with the different spectral signals. Herein, we report a simple but effective method by conjugating $\mathrm{H}_{2} \mathrm{~S}$-sensitive and phosphatase-sensitive fluorophores in a single molecular probe to simultaneously measure the $\mathrm{H}_{2} \mathrm{~S}$ level and the phosphatase activity in live cells. The blue $\left(\right.$ to $\left.\mathrm{H}_{2} \mathrm{~S}\right)$ and green (to phosphatase) fluorescent responses together with their resonance energy transferring signal provide the threechannel fluorescent imaging of $\mathrm{H}_{2} \mathrm{~S}$ level, phosphatase activity, and their correlation. The current work reveals for the first time that the slight deviation of the $\mathrm{H}_{2} \mathrm{~S}$ level from an ideal value leads to the sharp decrease of phosphatase activity in live cells. 
Here, we selected coumarin (emission at $445 \mathrm{~nm}$ ) and rhodol (emission at $545 \mathrm{~nm}$ ) to construct the molecular probe, following two main considerations: 1 ) the two emissive peaks were separated by roughly $100 \mathrm{~nm}$ to avoid spectral interference; 2) the emission spectra of coumarin overlaps with the absorption of rhodol (Figure S1), leading to Förster resonance energy transfer (FRET). ${ }^{[14]}$ Figure 1 a gives the probe structure that comprises a two fluorophores, $\mathrm{N}_{3}$-modified coumarin and phosphate-modified rhodol, connected by a piperazine bridge. The synthetic protocol is shown in Scheme S1 of the Supporting Information. Simply, a carboxyl coumarin was synthesized and further modified with $-\mathrm{N}_{3}$, which shut off the blue emission due to the strong electronwithdrawing effect of this functional group. ${ }^{[9]}$ Then, the coumarin derivative was linked to rhodol with a piperazine

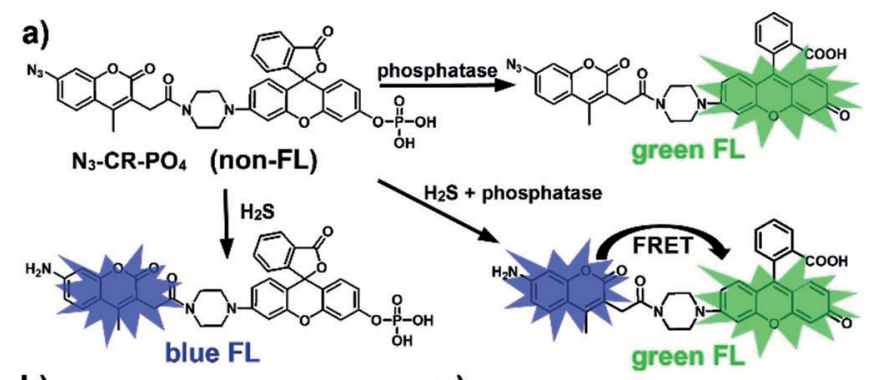

b)

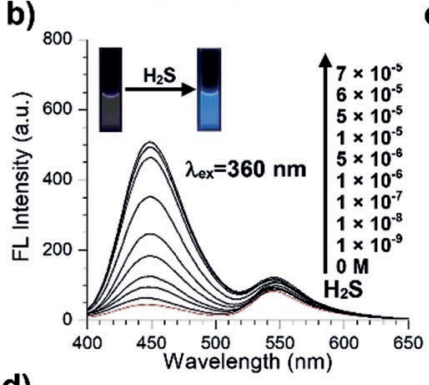

c)
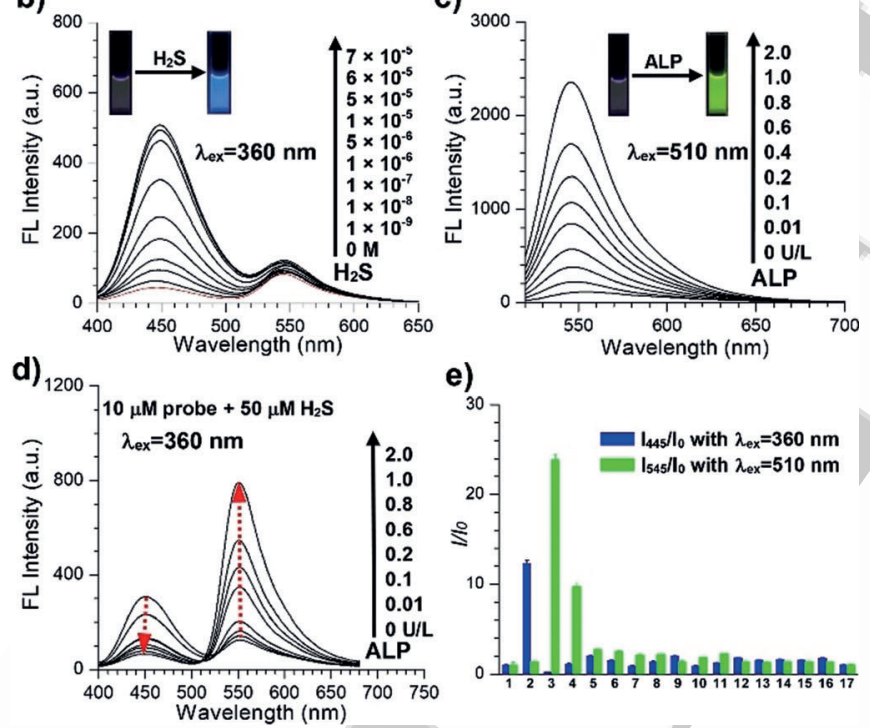

Figure 1. a) Fluorescent response mechanisms of probe $\mathrm{N}_{3}-\mathrm{CR}-\mathrm{PO}_{4}$ to $\mathrm{H}_{2} \mathrm{~S}$, phosphatase, and $\mathrm{H}_{2} \mathrm{~S} /$ phosphatase mixture. b) Fluorescence spectra of $10 \mu \mathrm{M} \mathrm{N} \mathrm{N}_{3}-\mathrm{CR}-\mathrm{PO}_{4}$ with the addition of $\mathrm{H}_{2} \mathrm{~S}$ in Tris- $\mathrm{HCl}$ buffer (pH 7.2) for $1 \mathrm{~h}$; excitation: $360 \mathrm{~nm}$. c) Fluorescence spectra of $10 \mu \mathrm{M}$ $\mathrm{N}_{3}-\mathrm{CR}-\mathrm{PO}_{4}$ with the addition of ALP in Tris- $\mathrm{HCl}$ buffer $(\mathrm{pH} 8.0)$; excitation: $510 \mathrm{~nm}$; the insets are the corresponding photographs under $365 \mathrm{~nm}$ UV lamp. d) Fluorescence spectra upon mixing $10 \mu \mathrm{M}$ $\mathrm{N}_{3}-\mathrm{CR}-\mathrm{PO}_{4}$ and $50 \mu \mathrm{M} \mathrm{H} \mathrm{H}_{2} \mathrm{~S}$ and adding ALP; excitation: $360 \mathrm{~nm}$ $(\mathrm{pH} 8.0)$. e) The selectivity of fluorescent responses $\left(I / I_{0}\right)$ to various biomolecules in $10 \mu \mathrm{M} \mathrm{N} \mathrm{N}_{3}-\mathrm{CR}_{-} \mathrm{PO}_{4}$ solution. 1: blank, 2: $60 \mu \mathrm{M} \mathrm{H} \mathrm{H}_{2} \mathrm{~S}$, 3: $2 \mathrm{UL}^{-1}$ ALP, 4: $100 \mathrm{mg} \mathrm{L}^{-1}$ ACP, 5: $60 \mu \mathrm{M} \mathrm{Na} \mathrm{N}_{2}, 6: 60 \mu \mathrm{M} \mathrm{Na} \mathrm{S}_{2 \approx 6}$, 7: $100 \mu \mathrm{M}$ NaSCN, 8: $100 \mu \mathrm{M} \mathrm{Na} \mathrm{SO}_{3}, 9: 100 \mu \mathrm{M} \mathrm{Na} \mathrm{S}_{2} \mathrm{O}_{3}, 10: 100 \mu \mathrm{M}$ Cys, 11: $100 \mu \mathrm{M}$ GSH, 12:10 UL $\mathrm{L}^{-1}$ AchE, 13:10 UL $\mathrm{L}^{-1} \mathrm{GDH}$,

14: $10 \mathrm{UL}^{-1} \mathrm{COX}, 15: 10 \mathrm{UL}^{-1}$ thrombin, 16: $250 \mathrm{mg} \mathrm{L}^{-1}$ trypsin, 17: $10 \mathrm{UL}^{-1} \mathrm{PDE}$. The error bars represent the mean errors from the results of 5 tests. bridge through an amidation reaction. Finally, phosphate was grafted onto rhodol to obtain our probe $\mathrm{N}_{3}-\mathrm{CR}-\mathrm{PO}_{4}$; the green emission of rhodol is shut off since spirocyclization interrupts the $\pi$-conjugation. ${ }^{[13]}$ After purification, $\mathrm{N}_{3}-\mathrm{CR}$ $\mathrm{PO}_{4}$ was characterized by $\mathrm{HRMS}$, and ${ }^{1} \mathrm{H},{ }^{13} \mathrm{C}$ and ${ }^{31} \mathrm{P}$ NMR spectroscopy (Figures S2-S5).

One the one hand, the blue fluorescence of probe $\mathrm{N}_{3}$-CR$\mathrm{PO}_{4}$ is turned on by $\mathrm{H}_{2} \mathrm{~S}$ via the reduction of $-\mathrm{N}_{3}$ to $-\mathrm{NH}_{2}$; on the other hand, its phosphate group can be catalytically cleaved by phosphatase, leading to recovery of the green fluorescence of rhodol (Figure 1a). In the presence of both $\mathrm{H}_{2} \mathrm{~S}$ and phosphatase, only green fluorescence is detected with the optimal excitation wavelength of coumarin, owing to FRET from coumarin to rhodol. However, this signal is different from the green emission induced by phosphatase alone, which is rather weak at this excitation wavelength. The reaction of the probe with $\mathrm{H}_{2} \mathrm{~S}$ and phosphatase has been certified by high-performance liquid chromatography (Figure S6).

The sensitivity of the probe was examined by a series of measurements of fluorescent responses to $\mathrm{H}_{2} \mathrm{~S}$ and alkaline phosphatase (ALP) in Tris-HCl buffer (Figure $1 \mathrm{~b}-\mathrm{d}$ ). Before the test, the original probe showed two weak fluorescence peaks at 445 and $545 \mathrm{~nm}$ (excitation: $360 \mathrm{~nm}$; red curve in Figure $1 \mathrm{~b}$ ). Upon addition of $\mathrm{H}_{2} \mathrm{~S}$ to the $\mathrm{N}_{3}-\mathrm{CR}-\mathrm{PO}_{4}$ solution, the fluorescent peaks at $445 \mathrm{~nm}$ gradually became stronger, and finally reached $\approx 13$ times enhancement at $70 \mu \mathrm{M} \mathrm{H}_{2} \mathrm{~S}$. Even at $1 \mathrm{nM} \mathrm{H}_{2} \mathrm{~S}, \approx 1$.4-fold fluorescence enhancement indicated the high sensitivity of the probe to $\mathrm{H}_{2} \mathrm{~S}$. The fluorescence intensity exhibited a linear relationship vs. $\mathrm{H}_{2} \mathrm{~S}$ amount from 10 to $60 \mu \mathrm{M}$ (standard deviation $R^{2}=0.999$, Figure S8). Meanwhile, the blue fluorescence could be clearly seen under a UV lamp (inset in Figure $1 \mathrm{~b}$ ). It was noted that the other weak emission at $545 \mathrm{~nm}$ remained almost unchanged throughout the titration.

With the addition of ALP, the probe as a substrate of phosphatase showed an apparent and continuous increase of fluorescent peak at $545 \mathrm{~nm}$ (excitation: $510 \mathrm{~nm}$; Figure 1c). The maximum enhancement was up to $\approx 23$ fold at $2 \mathrm{UL}^{-1}$ ALP. Even at $0.01 \mathrm{UL}^{-1}$ ALP, fluorescence still increased by a factor of 2, suggesting the supersensitivity of the probe to phosphatase. We observed that the solution color changed from colorless to bright green under a UV lamp (inset in Figure $1 \mathrm{c}$ ). The fluorescence intensities exhibited a linear relationship against ALP amounts from 0.01 to $1 \mathrm{UL}^{-1}$ (standard deviation $R^{2}=0.995$, Figure S9).

Because the coexistence of $\mathrm{H}_{2} \mathrm{~S}$ and ALP is very common in biological systems, the performance of the probe in this situation was verified in vitro by the addition of both $\mathrm{H}_{2} \mathrm{~S}$ and ALP. A $10 \mu \mathrm{M}$ solution of the probe was first mixed with $50 \mu \mathrm{M}$ $\mathrm{H}_{2} \mathrm{~S}$; this is close to the average $\mathrm{H}_{2} \mathrm{~S}$ level in many biological samples. ${ }^{[15]}$ After 20 min the solution showed a blue emission at $445 \mathrm{~nm}$ (excitation: $360 \mathrm{~nm}$ ). With the further addition of ALP to this solution, the peak at $445 \mathrm{~nm}$ decreased rapidly, while the fluorescence at $545 \mathrm{~nm}$ remarkably increased up to $\approx 7$-fold (Figure 1d). These phenomena confirm the occurrence of efficient FRET from coumarin to rhodol (Figure 1a). In the absence of $\mathrm{H}_{2} \mathrm{~S}$, however, only a slight enhancement of green fluorescence was detected upon excitation at $360 \mathrm{~nm}$ 
(Figure S10). In comparison, $\approx 72 \%$ fluorescence enhancement at $545 \mathrm{~nm}$ results from FRET in the coexisting system. The spectral signal forms the basis of the third-channel detection in fluorescent imaging (see the following text).

Before transfering the in vitro experiments to cellular imaging, we tested the effects of $\mathrm{pH}$ on the fluorescent signals of the probe sensing $\mathrm{H}_{2} \mathrm{~S}$ and phosphatase. In the range of $\mathrm{pH} 5-9$, the probe itself remained almost non-fluorescent; however, its three products formed by reaction with $\mathrm{H}_{2} \mathrm{~S}$, phosphatase, and both of them (Figure 1 a) exhibited strong and stable fluorescence (Figure S11). Similar to the previously reported probe, ${ }^{[16]}$ the protonation of the piperazine group slightly decreased the green fluorescent signal from phosphatase at $\mathrm{pH} 5$.

Moreover, we examined the selectivity of the probe using several kinds of molecules that commonly exist in live cells, including amino acids, peptides, proteins, enzymes, and inorganic salts (Figure 1e). The additions of Cys, glutathione $(\mathrm{GSH})$, glucose oxidase (GOX), acetylcholinesterase (AchE), phosphodiesterase (PDE), glucose dehydrogenase (GDH), thrombin, trypsin, $\mathrm{Na}_{2} \mathrm{~S}_{2}, \mathrm{Na}_{2} \mathrm{~S}_{2-6}, \mathrm{NaSCN}, \mathrm{Na}_{2} \mathrm{SO}_{3}$, and $\mathrm{Na}_{2} \mathrm{~S}_{2} \mathrm{O}_{3}$ to the probe solution did not cause any significant fluorescence enhancement upon excitation at either 360 or $510 \mathrm{~nm}$. Only $\mathrm{H}_{2} \mathrm{~S}$ induced strong blue emission (excitation: $360 \mathrm{~nm}$ ), while phosphatase including ALP and acid phosphatase (ACP) remarkably enhanced green emission at $545 \mathrm{~nm}$. Particularly, polysulfides still did not trigger the fluorescent response of probe, suggesting the high selectivity of probe to $\mathrm{H}_{2} \mathrm{~S}$ and phosphatase.

Before fluorescent imaging, the toxicity of probe was evaluated by classical MTT assay (Figure S12), and the results showed that our probe was nontoxic to cells in the concentration range of $1-20 \mu \mathrm{M}$.

Next, we set a three-channel imaging procedure to simultaneously detect $\mathrm{H}_{2} \mathrm{~S}$ and phosphatase: $\mathrm{CH} 1$ : excitation at $405 \mathrm{~nm}$ and collection in $420-470 \mathrm{~nm}$ for $\mathrm{H}_{2} \mathrm{~S}$; $\mathrm{CH} 2$ : excitation at $510 \mathrm{~nm}$ and collection in $530-570 \mathrm{~nm}$ for phosphatase; $\mathrm{CH} 3$ : excitation at $405 \mathrm{~nm}$ and collection in 530-570 nm for FRET correlation for coexisting $\mathrm{H}_{2} \mathrm{~S}$ and phosphatase (Table S1). When HeLa cells were treated with $10 \mu \mathrm{M}$ probe alone, all of the channels gave strong fluorescent signals (Figure $2 \mathrm{a}$ ), indicating that endogenous $\mathrm{H}_{2} \mathrm{~S}$ and phosphatase are sufficient to turn on the fluorescence of the probe in live cells. Especially, the bright fluorescence in $\mathrm{CH} 3$ suggests a highly efficient reaction of probe with both $\mathrm{H}_{2} \mathrm{~S}$ and phosphatase. To confirm the origin of the fluorescence signals, negative control experiments were performed by employing a phosphatase inhibitor $\left(\mathrm{Na}_{3} \mathrm{VO}_{4}\right)^{[6 \mathrm{a}]}$ and an $\mathrm{H}_{2} \mathrm{~S}$ generating enzyme inhibitor (aminooxyacetic acid, AOAA) ${ }^{[17]}$ After the cells were sequentially treated with $\mathrm{Na}_{3} \mathrm{VO}_{4}$ and the probe, the fluorescences in $\mathrm{CH} 2$ and $\mathrm{CH} 3$ from phosphatase obviously reduced, but the fluorescent signal in $\mathrm{CH} 1$ from $\mathrm{H}_{2} \mathrm{~S}$ became slightly stronger due to the interruption of FRET when phosphatase activity had been inhibited greatly (middle column of Figure 2 a). Indeed, green fluorescence results from the phosphatase and FRET between the two fluorophores in cells.

In another control group, the addition of AOAA would inhibit the further production of endogenous $\mathrm{H}_{2} \mathrm{~S}$ to reduce
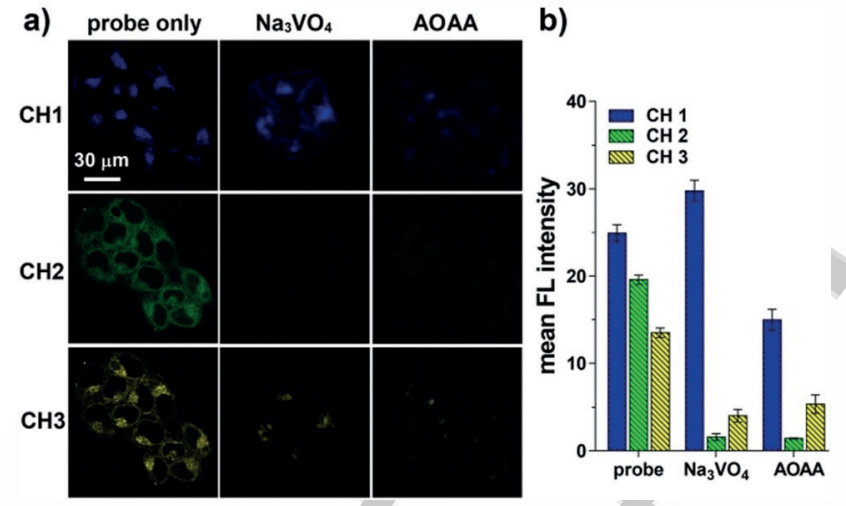

Figure 2. Simultaneous visualization of $\mathrm{H}_{2} \mathrm{~S}$ level and phosphatase activity in HeLa cells. a) Left column: HeLa cells were treated with $10 \mu \mathrm{M} \mathrm{N} \mathrm{N}_{3}-\mathrm{CR}-\mathrm{PO}_{4}$ for $30 \mathrm{~min}$; Middle column: HeLa cells were treated with $100 \mu \mathrm{M} \mathrm{Na} \mathrm{VO}_{4}$ for 30 min and then incubated with $10 \mu \mathrm{M} \mathrm{N}{ }_{3}$-CR$\mathrm{PO}_{4}$; Right column: HeLa cells were treated with $100 \mu \mathrm{M}$ AOAA for $30 \mathrm{~min}$, and then incubated with $10 \mu \mathrm{M} \mathrm{N} \mathrm{N}_{3}-\mathrm{CR}-\mathrm{PO}_{4}$. b) Statics fluorescence intensities of (a). The error bars represent standard deviation ( \pm $\mathrm{SD})$.

the level of $\mathrm{H}_{2} \mathrm{~S}$ in cells, leading to a weaker fluorescence in $\mathrm{CH} 1$ (right column of Figure 2a). Surprisingly, the fluorescent signals from $\mathrm{CH} 2$ and $\mathrm{CH} 3$ became rather weak, roughly commensurate with those upon the addition of phosphatase inhibitor $\mathrm{Na}_{3} \mathrm{VO}_{4}$ (Figure 2b). This suggests that the decrease of the $\mathrm{H}_{2} \mathrm{~S}$ level may result in phosphatase inactivation in live cells.

To verify $\mathrm{H}_{2} \mathrm{~S}$ regulation of phosphatase activity, we treated cells with the $\mathrm{H}_{2} \mathrm{~S}$ scavenger phorbol 12-myristate 13acetate (PMA) to decrease intracellular $\mathrm{H}_{2} \mathrm{~S}$ level, and then subsequently added $10 \mu \mathrm{M}$ probe solution. With increasing the PMA dose, the fluorescent signals from all three channels became gradually weaker (Figure $3 \mathrm{a}, \mathrm{b}$ ). Particularly, the signals in $\mathrm{CH} 2$ and $\mathrm{CH} 3$ almost disappeared. That is, the decrease in the $\mathrm{H}_{2} \mathrm{~S}$ level greatly inhibits the activity of phosphatase, confirming $\mathrm{H}_{2} \mathrm{~S}$ as an activator to maintain the normal activity of phosphatase in cells.

To further examine the effect of $\mathrm{H}_{2} \mathrm{~S}$ on phosphatase activity, we tried to study the performance of phosphatase at elevated $\mathrm{H}_{2} \mathrm{~S}$ levels in cells. HeLa cells were treated with different doses of $\mathrm{H}_{2} \mathrm{~S}$ and then incubated with $10 \mu \mathrm{M}$ probe solution. As shown in Figure $3 \mathrm{c}$ and $3 \mathrm{~d}$, the fluorescent signal from $\mathrm{CH} 1$ was gradually enhanced with the increase of $\mathrm{H}_{2} \mathrm{~S}$. In contrast, however, the signals in $\mathrm{CH} 2$ and $\mathrm{CH} 3$ became weaker and weaker. With the addition of only $10 \mu \mathrm{M} \mathrm{H}_{2} \mathrm{~S}$, the signal intensity in $\mathrm{CH} 2$ decreased at least to half. More $\mathrm{H}_{2} \mathrm{~S}$ supplement (e.g. $60 \mu \mathrm{M})$ led to almost disappearance of $\mathrm{CH} 2$ signal (Figure $3 \mathrm{~d}$ ). The same results were also obtained in other cell lines (Figures S13 and S14). Together with these above results, it is evident that phosphatase activity rapidly decreases when the concentration of $\mathrm{H}_{2} \mathrm{~S}$ deviating from its normal level in cells.

It should be noted that the blue and green fluorescences did not completely overlap in the three-channel imaging. The inconsistent localizations should result from the different products produced by the probe reacting with $\mathrm{H}_{2} \mathrm{~S}$ and phosphatase. To clarify this, we have performed the co-

These are not the final page numbers! 

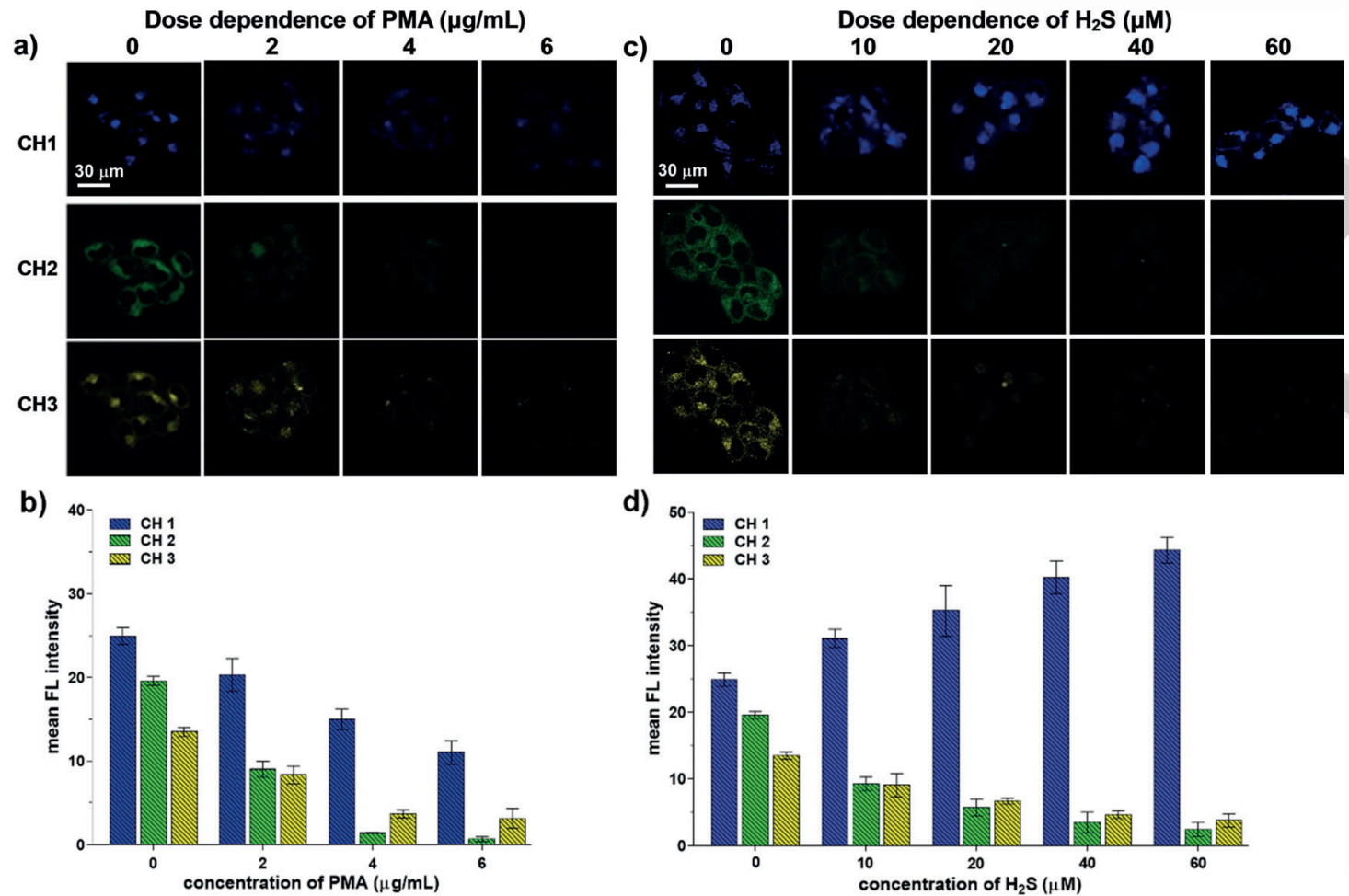

Figure 3. The dependence of phosphatase activity on $\mathrm{H}_{2} \mathrm{~S}$ level in live cells. a) HeLa cells were treated with different concentrations of $\mathrm{H}_{2} \mathrm{~S}$ scavenger (PMA) for $3 \mathrm{~h}$ and then incubated with $10 \mu \mathrm{M} \mathrm{N}-\mathrm{CR}-\mathrm{PO}_{4}$. b) Statics fluorescence intensities corresponding to the fluorescent imaging in (a). c) HeLa cells were treated with different concentrations of $\mathrm{H}_{2} \mathrm{~S}$ for 30 min and then incubated with $10 \mu \mathrm{M} \mathrm{N}_{3}-\mathrm{CR}-\mathrm{PO} \mathrm{O}_{4}$. d) Statics fluorescence intensity corresponding to the fluorescent imaging in (c). The error bars represent standard deviation ( \pm SD).

localization experiments of the three different products (obtained from the pre-reaction in vitro as inFigure $1 \mathrm{a}$ ). Indeed, most of the products from the reactions of the probe with $\mathrm{H}_{2} \mathrm{~S}$ and $\mathrm{H}_{2} \mathrm{~S}$ /phosphatase entered the lysosomes in cells by co-localization, while the reaction product of the probe with phosphatase alone randomly distributed in cytoplasm (Figure S15).

Moreover, we have also performed control experiments by combining two commercial probes: 7 -azidocoumarin for $\mathrm{H}_{2} \mathrm{~S}$ and fluorescein diphosphate for phosphatase. The blue and green fluorescent signals for $\mathrm{H}_{2} \mathrm{~S}$ and phosphatase, respectively, exhibited the same trends displayed in experiments with our single probe (Figure 3 and Figure S16). Here, a detected difference from our results is that the addition of $\mathrm{H}_{2} \mathrm{~S}$ scavenger sharply decreased the activity of phosphatase almost to its minimum. One main reason may be the high cytotoxicity from the combination of the two probes (Figure S12); the cell viability decreased by $60 \%$ at the probe concentration used $(10 \mu \mathrm{M})$. The toxic stress would stimulate cells to generate more ROS which could further decrease the $\mathrm{H}_{2} \mathrm{~S}$ level in the cells, greatly lowering phosphatase activity.

We have also used $\mathrm{H}_{2} \mathrm{~S}$ and phosphatase kits to verify the above results. First, HeLa cells were incubated with PMA and $\mathrm{H}_{2} \mathrm{~S}$ to lower and elevate intracellular $\mathrm{H}_{2} \mathrm{~S}$ levels, respectively. After washing, these cells were lysed to obtain cell lysates, and the $\mathrm{H}_{2} \mathrm{~S}$ level and phosphatase activity were measured by kits. Figure 4 shows that the phosphatase activity is the highest in the control group with the normal level of $\mathrm{H}_{2} \mathrm{~S}(\approx 55 \mu \mathrm{M})$. When the $\mathrm{H}_{2} \mathrm{~S}$ level rose or fell by $\approx 10 \mu \mathrm{M}$, phosphatase activity sharply decreased by at least $50 \%$, and then showed a continuous decrease with further deviations of $\mathrm{H}_{2} \mathrm{~S}$ level from the normal value, which was in agreement with the results from fluorescent imaging.

Previous biological studies mainly focused on phosphatase activity at elevated $\mathrm{H}_{2} \mathrm{~S}$ levels, ${ }^{[4 \mathrm{~d}, \mathrm{e}]}$ and showed the inhibition of phosphatase activity with the increase of intra-

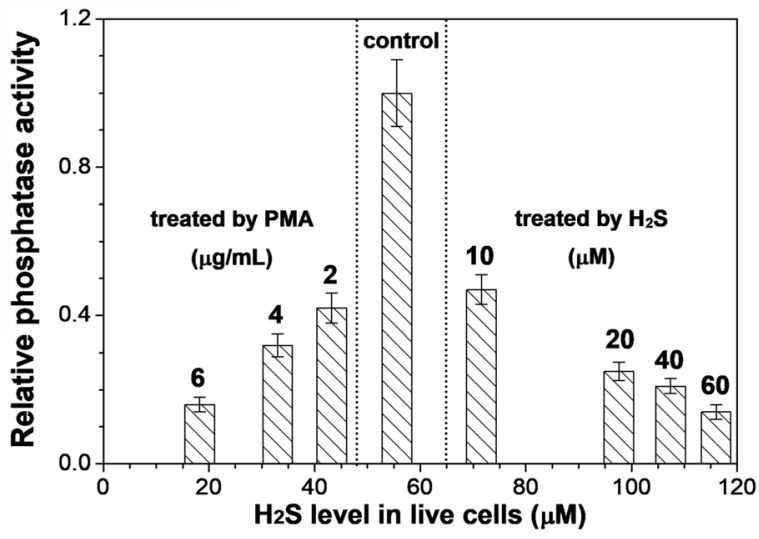

Figure 4. Relation between $\mathrm{H}_{2} \mathrm{~S}$ level and phosphatase activity. The $\mathrm{H}_{2} \mathrm{~S}$ level and phosphatase activity were measured in cell lysates by kit tests. In the control groups, HeLa cells were untreated. In the group treated with PMA, the cells were incubated with different amounts of PMA for $3 \mathrm{~h}$. In group treated with $\mathrm{H}_{2} \mathrm{~S}$, the cells were incubated with different concentrations of $\mathrm{H}_{2} \mathrm{~S}$ for $30 \mathrm{~min}$. The error bars represent the mean errors from the results of 3 tests. 
cellular $\mathrm{H}_{2} \mathrm{~S}$ level, which is consistent with our results here. However, phosphatase activity with a decrease of intracellular $\mathrm{H}_{2} \mathrm{~S}$ level has been rarely explored. In our present work we found that there is an critical $\mathrm{H}_{2} \mathrm{~S}$ level in cells to control the activity of phosphatase.

In summary, we have successfully designed and synthesized a dual-reactive molecular probe that can respond to both $\mathrm{H}_{2} \mathrm{~S}$ and phosphatase with two differentiable fluorescent signals. The combination with the FRET signal between these fluorescence signals established a three-channel imaging method to detect $\mathrm{H}_{2} \mathrm{~S}$ and phosphatase activity in live cells, and to clarify the correlation of phosphatase activity with $\mathrm{H}_{2} \mathrm{~S}$ level. Importantly, the results reported here reveal that cells have an ideal $\mathrm{H}_{2} \mathrm{~S}$ level to maintain the high activity of phosphatase, and the slight deviations from the ideal value will significantly reduce the activity of phosphatase. This significant discovery indicates that fluorescent probes will become a powerful tool to explore the regulatory mechanisms of enzyme activity in live organisms.

\section{Acknowledgements}

This work was supported by National Basic Research Program of China (2015CB932002), National Natural Science Foundation of China (21335006, 21475135, 21375131, 21775001, 21705001, and 21602003), Anhui Provincial Natural Science Foundation of China (1708085MC68 and 1808085MB32), and Hefei Physical Science Center Foundation (2017FXZY001).

\section{Conflict of interest}

The authors declare no conflict of interest.

Keywords: enzyme regulation - fluorescent probes gasotransmitters · imaging agents · phosphatase

[1] a) G. W. Li, D. Burkhardt, C. Gross, J. S. Weissman, Cell 2014 157, 624; b) E. Barkauskaite, G. Jankevicius, I. Ahel, Mol. Cell 2015, 58,935 .

[2] a) N. K. Tonks, Nat. Rev. Mol. Cell Biol. 2006, 7, 833; b) W. W. Winder, B. F. Holmes, D. S. Rubink, E. B. Jensen, M. Chen, J. O. Holloszy, J. Appl. Physiol. 2000, 88, 2219.

[3] a) H. Kamata, S. I. Honda, S. Maeda, L. Chang, H. Hirata, M. Karin, Cell 2005, 120, 649; b) K. Hensley, K. A. Robinson, S. P. Gabbita, S. Salsman, R. A. Floyd, Free Radical Biol. Med. 2000 28, 1456; c) A. Caselli, G. Camici, G. Manao, G. Moneti, L. Pazzagli, G. Cappugi, G. Ramponi, J. Biol. Chem. 1994, 269, 24878 .
[4] a) H. Kimura, N. Shibuya, Y. Kimura, Antioxid. Redox Signaling 2012, 17, 45; b) P. D. Ray, B. W. Huang, Y. Tsuji, Cell. Signalling 2012, 24, 981; c) M. R. Filipovic, J. Zivanovic, B. Alvarez, R. Banerjee, Chem. Rev. 2018, 118, 1253; d) N. Krishnan, C. Fu, D. J. Pappin, N. K. Tonks, Sci. Signaling 2011, 4, ra86; e) V. Yadav, X. H. Gao, B. Willard, M. Hatzoglou, R. Banerjee, O. Kabil, J. Biol. Chem. 2017, 292, 13143.

[5] a) H. Kimura, Molecules 2014, 19, 16146; b) S. K. Lee, J. H. Chung, S. C. Choi, Q. S. Auh, Y. M. Lee, S. I. Lee, E. C. Kim, J. Cell. Biochem. 2013, 114, 1183.

[6] a) H. W. Liu, K. Li, X. X. Hu, L. Zhu, Q. Rong, Y. Liu, X. B. Zhang, J. Hasserodt, F. L. Qu, W. Tan, Angew. Chem. Int. Ed. 2017, 56, 11788; Angew. Chem. 2017, 129, 11950; b) S. J. Li, C. Y. Li, Y. F. Li, J. Fei, P. Wu, B. Yang, J. Ou-Yang, S. X. Nie, Anal. Chem. 2017, 89, 6854

[7] a) L. Li, J. Ge, H. Wu, Q. H. Xu, S. Q. Yao, J. Am. Chem. Soc. 2012, 134, 12157; b) L. Li, X. Shen, Q. H. Xu, S. Q. Yao, Angew. Chem. Int. Ed. 2013, 52, 424; Angew. Chem. 2013, 125, 442.

[8] a) K. Sasakura, K. Hanaoka, N. Shibuya, Y. Mikami, Y. Kimura, T. Komatsu, T. Ueno, T. Terai, H. Kimura, T. Nagano, J. Am. Chem. Soc. 2011, 133, 18003; b) Y. Ma, H. Su, X. Kuang, X. Li, T. Zhang, B. Tang, Anal. Chem. 2014, 86, 11459.

[9] a) V. S. Lin, W. Chen, M. Xian, C. J. Chang, Chem. Soc. Rev. 2015, 44, 4596; b) Y. Chen, C. Zhu, Z. Yang, J. Chen, Y. He, Y. Jiao, W. He, L. Qiu, J. Cen, Z. Guo, Angew. Chem. Int. Ed. 2013, 52, 1688; Angew. Chem. 2013, 125, 1732; c) C. R. Liu, J. Pan, S. Li, Y. Zhao, L. Y. Wu, C. E. Berkman, A. R. Whorton, M. Xian, Angew. Chem. Int. Ed. 2011, 50, 10327; Angew. Chem. 2011, 123, 10511; d) Y. Qian, J. Karpus, O. Kabil, S. Y. Zhang, H. L. Zhu, R. Banerjee, J. Zhao, C. He, Nat. Commun. 2011, 2, 495.

[10] a) H. Peng, Y. Cheng, C. Dai, A. L. King, B. L. Predmore, D. J. Lefer, B. Wang, Angew. Chem. Int. Ed. 2011, 50, 9672; Angew. Chem. 2011, 123, 9846; b) S. Chen, Z. Chen, W. Ren, H. Ai, J. Am. Chem. Soc. 2012, 134, 9589.

[11] a) A. R. Lippert, E. J. New, C. J. Chang, J. Am. Chem. Soc. 2011, 133, 10078; b) M. K. Thorson, T. Majtan, J. P. Kraus, A. M. Barrios, Angew. Chem. Int. Ed. 2013, 52, 4641; Angew. Chem. 2013, 125, 4739 .

[12] a) L. Yuan, W. Lin, Y. Xie, B. Chen, S. Zhu, J. Am. Chem. Soc. 2012, 134, 1305; b) R. Zhang, J. Zhao, G. Han, Z. Liu, C. Liu, C. Zhang, B. Liu, C. Jiang, R. Liu, T. Zhao, M. Y. Han, Z. Zhang, J. Am. Chem. Soc. 2016, 138, 3769.

[13] W. Chen, A. Pacheco, Y. Takano, J. J. Day, K. Hanaoka, M. Xian, Angew. Chem. Int. Ed. 2016, 55, 9993; Angew. Chem. 2016, 128, 10147.

[14] a) H. Takakusa, K. Kikuchi, Y. Urano, H. Kojima, T. Nagano, Chem. Eur. J. 2003, 9, 1479; b) A. E. Albers, V. S. Okreglak, C. J. Chang, J. Am. Chem. Soc. 2006, 128, 9640; c) L. Yuan, W. Lin, K. Zheng, S. Zhu, Acc. Chem. Res. 2013, 46, 1462.

[15] K. R. Olson, E. R. DeLeon, F. Liu, Nitric Oxide 2014, 41, 11.

[16] S. Jia, K. M. Ramos-Torres, S. Kolemen, C. M. Ackerman, C. J. Chang, ACS Chem. Biol. 2018, 13, 1844.

[17] C. Szabo, C. Coletta, C. Chao, K. Módis, B. Szczesny, A. Papapetropoulos, M. R. Hellmich, Proc. Natl. Acad. Sci. USA 2013, 110, 12474.

Manuscript received: October 3, 2018

Revised manuscript received: November 25, 2018

Accepted manuscript online: December 27, 2018

Version of record online: 


\section{Communications}

Fluorescent Probes

P. Ou, R. Zhang,* Z. Liu, X. Tian, G. Han,

B. Liu, Z. Hu, Z. Zhang*

III-III

Gasotransmitter Regulation of

Phosphatase Activity in Live Cells Studied

by Three-Channel Imaging Correlation

Fluoreszenzsonden

P. Ou, R. Zhang,* Z. Liu, X. Tian, G. Han,

B. Liu, Z. Hu, Z. Zhang*

IIII-IIII

Gasotransmitter Regulation of

Phosphatase Activity in Live Cells Studied by Three-Channel Imaging Correlation

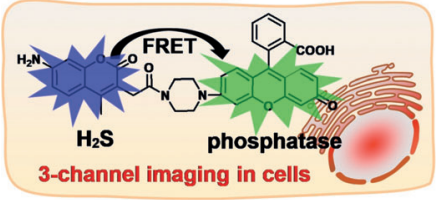

\section{${ }^{80} \mathrm{H}_{2} \mathrm{~S}$ channel}

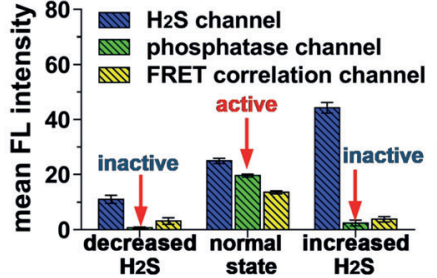

Two for one: A dual-reactive molecular probe has been devised to simultaneously measure intracellular $\mathrm{H}_{2} \mathrm{~S}$ levels and phosphatase activity. Fluorescent analysis by three-channel imaging correlation reveals that a slight deviation from the normal $\mathrm{H}_{2} \mathrm{~S}$ level leads to a sharp decrease of phosphatase activity.

Eine molekulare Sonde mit dualer Reaktivität kann simultan intrazelluläre $\mathrm{H}_{2} \mathrm{~S}$ Niveaus und Phosphatase-Aktivität messen. Eine Fluoreszenzanalyse durch Drei-Kanal-Imaging-Korrelation ergibt, dass eine leichte Abweichung vom normalen $\mathrm{H}_{2} \mathrm{~S}$-Niveau zu einer drastischen Abnahme der Phosphatase-Aktivität führt. 
Please check that the ORCID identifiers listed below are correct. We encourage all authors to provide an ORCID identifier for each coauthor. ORCID is a registry that provides researchers with a unique digital identifier. Some funding agencies recommend or even require the inclusion of ORCID IDs in all published articles, and authors should consult their funding agency guidelines for details. Registration is easy and free; for further information, see http://orcid.org/.

$\mathrm{Pan} \mathrm{Ou}$

Ruilong Zhang

Zhengjie Liu

Xiaohe Tian

Guangmei Han

Bianhua Liu

Zhangjun $\mathrm{Hu}$

Prof. Zhongping Zhang http://orcid.org/0000-0002-0991-7611 